\title{
Inability of Plasma and Urine F2A-Isoprostane Levels to Differentiate Mild Cognitive Impairment from Alzheimer's Disease
}

\author{
Elliott J. Mufson ${ }^{a}$ Sue Leurgans ${ }^{b}$ \\ a Department of Neurological Sciences, and ${ }^{\mathrm{b}}$ Rush Alzheimer's Disease Center, Rush University Medical Center, \\ Chicago, III., USA
}

\section{Key Words}

Alzheimer's disease biomarkers $\cdot$ Isoprostane $\cdot$ Mild cognitive impairment $\cdot$ Oxidative stress

\begin{abstract}
Background: Oxidative stress has been implicated in the pathogenesis of Alzheimer's disease (AD). The pathobiological changes related to AD occur long before the overt clinical symptoms. The plasma lipid peroxidation enzyme F2-isoprostane has been suggested as a biomarker to detect the progression from mild cognitive impairment $(\mathrm{MCl})$ to $A D$. Objective: To test whether plasma and urine F2-isoprostane was diagnostic for dementia in living people. Methods: Plasma and urine were collected from 222 Religious Orders Study participants with a clinical diagnosis of no cognitive impairment, $\mathrm{MCl}$ or $\mathrm{AD}$ at time of fluid collection. Isoprostane levels were determined using gas chromatography/ mass spectroscopy. Results: Plasma and urine F2-isoprostane levels did not differ between the three clinical groups. Postmortem neuropathologic diagnosis of subjects who died during the course of the study was not associated with baseline blood or plasma F2-isoprostane levels. Conclusions: In living people, plasma or urine isoprostane levels were not sensitive enough to discriminate between individuals with a clinical diagnosis of no cognitive impairment, $\mathrm{MCl}$ or AD.

Copyright ๑ 2010 S. Karger AG, Basel
\end{abstract}

\section{Introduction}

Increases in brain markers of oxidation and reduced activities of antioxidant enzymes implicate oxidative damage in the pathobiology of Alzheimer's disease (AD). Isoprostanes which arise from free radical-mediated peroxidation of polyunsaturated fatty acids were elevated in brain tissue and cerebral spinal fluid (CSF) obtained at autopsy in advanced and early AD [1-7], as well as in CSF harvested intra vitam from sporadic and familial AD [6, 8]. Since obtaining CSF via a spinal tap can be stressful and not easily obtained in most clinics, investigators have quantified isoprostanes in plasma and urine with studies showing increased [6] or no change [6,7] in early and late stage $\mathrm{AD}$. To assist in resolving this issue, we measured plasma and urine F2-isoprostane levels from a cohort of living people with a clinical diagnosis of no cognitive impairment (NCI), mild cognitive impairment (MCI) or $\mathrm{AD}$.

\section{Subjects and Methods}

Subjects

In 2003, plasma and urine samples were obtained antemortem from participants in the Religious Orders Study, a longitudinal clinical-pathological study of aging and AD $[1,9]$. Clinical diagnoses of AD dementia, MCI and NCI at the time of sample collection are based upon evaluation closest to fluid collection using previously described criteria [9]. At baseline, 167 (75\%) of the subjects were clinically classified as NCI, $34(15 \%)$ as MCI, and 21

\section{KARGER}

Fax +4161306 1234 E-Mail karger@karger.ch www.karger.com
Prof. Elliott J. Mufson, PhD

Rush University Medical Center

1735 W. Harrison Street, Suite 300

Chicago, IL 60612 (USA)

Tel. +1 312563 3558, Fax +1 312563 3571, E-Mail emufson@ rush.edu 
Table 1. Clinical characteristics of living subjects

\begin{tabular}{|c|c|c|c|c|c|}
\hline \multirow[t]{2}{*}{ Characteristic } & \multicolumn{4}{|c|}{ Baseline clinical diagnosis } & \multirow{2}{*}{$\begin{array}{l}\text { Comparison } \\
\text { by diagnosis } \\
\text { group, p }\end{array}$} \\
\hline & $\mathrm{NCI}(\mathrm{n}=167)$ & $\operatorname{MCI}(\mathrm{n}=34)$ & $\mathrm{AD}(\mathrm{n}=21)$ & total $(\mathrm{n}=222)$ & \\
\hline Males & $44(26 \%)$ & $8(24 \%)$ & $7(33 \%)$ & $59(27 \%)$ & $0.720^{\mathrm{a}}$ \\
\hline Years of education ${ }^{\mathrm{b}}$ & $17.7 \pm 3.0$ & $17.6 \pm 3.1$ & $18.3 \pm 3.4$ & $17.8 \pm 3.0$ & $0.141^{\mathrm{c}}$ \\
\hline ApoE $\varepsilon 4$ alleles & $39(24 \%)$ & $12(35 \%)$ & $10(48 \%)$ & $61(28 \%)$ & $0.044^{\mathrm{a}}$ \\
\hline Age at blood draw, years ${ }^{b}$ & $79.8 \pm 6.3$ & $83.5 \pm 5.9$ & $86.3 \pm 7.0$ & $80.9 \pm 6.6$ & $<0.0001^{\mathrm{c}}$ \\
\hline MMSE at blood draw ${ }^{\mathrm{b}}$ & $29.0 \pm 1.3$ & $27.4 \pm 2.2$ & $16.1 \pm 7.7$ & $27.6 \pm 4.6$ & $<0.0001^{\mathrm{c}}$ \\
\hline Global cognitive score ${ }^{\mathrm{b}}$ & $0.4 \pm 0.5$ & $-0.3 \pm 0.5$ & $-2.0 \pm 0.9$ & $0.1 \pm 0.9$ & $<0.0001^{\mathrm{c}}$ \\
\hline Subjects on statins & $50(30 \%)$ & $10(29 \%)$ & $3(14 \%)$ & $63(28 \%)$ & $0.32^{\mathrm{a}}$ \\
\hline Urine isoprostane, $\mathrm{ng} / \mathrm{mg}$ creatinine $\mathrm{e}^{\mathrm{d}, \mathrm{e}}$ & $2.8 \pm 126 \%$ & $2.6 \pm 170 \%$ & $3.9 \pm 105 \%$ & $2.8 \pm 132 \%$ & $0.246^{\mathrm{c}}$ \\
\hline Plasma isoprostane, $\mathrm{pg} / \mathrm{ml}^{\mathrm{d}, \mathrm{e}}$ & $107 \pm 73 \%$ & $111 \pm 87 \%$ & $138 \pm 70 \%$ & $109 \pm 75 \%$ & $0.250^{c}$ \\
\hline
\end{tabular}

MMSE $=$ Mini-Mental State Exam.

${ }^{\mathrm{a}} \chi^{2}$ test; ${ }^{\mathrm{b}}$ Mean $\pm \mathrm{SD} ;{ }^{\mathrm{c}}$ Kruskal-Wallis test; ${ }^{\mathrm{d}}$ ANOVA; ${ }^{\mathrm{e}} \mathrm{GM} \pm \mathrm{GCV}$.

(9\%) as AD. Subjects who died during the course of the study received a consensus conference final clinical diagnosis and their brains were neuropathologically examined according to CERAD [10], NIA-Reagan criteria [11] and Braak scoring [12]. ApoE genotyping was performed as previously reported [13].

\section{Isoprostane Levels}

Plasma and urine were cooled to $4^{\circ} \mathrm{C}$, spun within $15 \mathrm{~min}$, aliquoted as $960 \mu \mathrm{l}$ plasma with $40 \mu \mathrm{l} 20 \times$ protease inhibitor solution (Complete; Roche, Indianapolis, Ind., USA), and stored at $-80^{\circ} \mathrm{C}$ until measurement $[2-5,13]$. Levels of isoprostane iP $\alpha-V I$ (F2A) were determined by gas chromatography/mass spectroscopy $[2-5,13]$. The inter-and intra-assay variability of the assays was approximately $5 \%$.

\section{Statistical Analysis}

Since F2-isoprostane levels displayed a skewed distribution, the data are presented as the geometric means (GM) and geometric coefficients of variation (GCV), which are presented as GM \pm (GCV; percentage difference from the mean) [14]. F2-isoprostane, neuropathologic and demographic data were compared using analysis of variance (ANOVA) or Kruskal-Wallis test, gender distribution by a $\chi^{2}$ test, and association of plasma with urine F2isoprostane levels by the Spearman's rank correlation coefficient. Ordinal logistic regression examined the relationship between F2-isoprostane and neuropathologic data. Statistical significance was set at $\alpha=0.05$.

\section{Results}

At baseline, the mean age of the NCI (79.6 years) subjects was significantly less than that of both MCI (83.5 years) and AD (86.3 years) subjects (Kruskal-Wallis, $\mathrm{p}<$ 0.0001). Mini-Mental State Exam scores differed signifi- cantly among the groups (Kruskal-Wallis, p < 0.001); post-hoc testing showed that the means for the NCI (28.9) and MCI (27.4) groups did not differ significantly from each other, but both were significantly higher than that of the AD (16.2) group (table 1). ApoE $\varepsilon 4$ allele status differed significantly between the three clinical groups $\left(\chi^{2}=6.25 ; \mathrm{p}=0.044\right.$; table 1). Plasma F2-isoprostane levels were not associated with age, education, sex or use of statins ( $p>0.15)$; urine levels were higher for males ( $p=$ 0.026 , Spearman correlation) and those on statins had lower urine isoprostane levels $(\mathrm{p}=0.0244)$. F2-isoprostane levels were determined for 134 (74\%) NCI, 32 (18\%) MCI and 14 (8\%) AD cases. Plasma F2-isoprostane was not measured in 33 (22\%) NCI, 2 (6\%) MCI, and 7 (33\%) AD subjects. The overall GM \pm GCV for plasma F2-isoprostane was $107 \mathrm{pg} / \mathrm{ml} \pm 73 \%$, and $2.80 \mathrm{ng} / \mathrm{mg} \pm 132 \%$ for urine creatinine. Plasma and urine F2-isoprostane levels were not correlated (Spearman correlation, 0.67, $\mathrm{p}<0.0001)$ and did not differ among the three clinical groups at the time of specimen draw. Mean urine levels were $2.8 \mathrm{ng} / \mathrm{mg}$ creatinine for NCI, $2.6 \mathrm{ng} / \mathrm{mg}$ creatinine for MCI and $3.7 \mathrm{ng} / \mathrm{mg}$ creatinine for AD, and plasma F2isoprostane levels were $107 \mathrm{pg} / \mathrm{ml}$ for NCI, $111 \mathrm{pg} / \mathrm{ml}$ for $\mathrm{MCI}$ and $138 \mathrm{pg} / \mathrm{ml}$ for AD.

A consensus postmortem clinical evaluation of the 63 deceased subjects revealed 22 as NCI (2 were MCI at baseline; 20 were NCI), 15 as MCI (6 were NCI at baseline; 9 were $\mathrm{MCI}$ ) and 26 as $\mathrm{AD}$ (14 were $\mathrm{AD}$ at baseline, 5 were MCI and 7 were NCI; table 2). Although these clinical groups did not differ in Braak staging, by NIA-Reagan diagnosis the AD group was neuropathologically more 
Table 2. Neuropathological characteristics of deceased subjects

\begin{tabular}{|c|c|c|c|c|c|c|}
\hline \multirow[t]{2}{*}{ Neuropathology } & \multicolumn{4}{|c|}{ Consensus postmortem clinical diagnosis } & \multirow{2}{*}{$\begin{array}{l}\text { Comparison } \\
\text { by diagnosis } \\
\text { group }\end{array}$} & \multirow{2}{*}{$\begin{array}{l}\text { Pairwise } \\
\text { comparisons }\end{array}$} \\
\hline & $\begin{array}{l}\text { NCI } \\
(\mathrm{n}=22)\end{array}$ & $\begin{array}{l}\text { MCI } \\
(\mathrm{n}=15)\end{array}$ & $\begin{array}{l}\text { dementia } \\
(\mathrm{n}=26)\end{array}$ & $\begin{array}{l}\text { total } \\
(\mathrm{n}=63)\end{array}$ & & \\
\hline \multicolumn{7}{|c|}{ Distribution of Braak scores } \\
\hline 0 & 1 & 0 & 0 & 1 & \multirow[t]{4}{*}{$\mathrm{p}=0.291^{\mathrm{a}}$} & \multirow[t]{4}{*}{-} \\
\hline $\mathrm{I} / \mathrm{II}$ & 6 & 3 & 2 & 11 & & \\
\hline III/IV & 14 & 9 & 17 & 40 & & \\
\hline $\mathrm{V}$ & 1 & 3 & 7 & 11 & & \\
\hline \multicolumn{7}{|c|}{ Distribution of NIA Reagan diagnosis (likelihood of AD) } \\
\hline No AD & 0 & 0 & 0 & 0 & \multirow[t]{4}{*}{$\mathrm{p}=0.004^{\mathrm{a}}$} & \multirow[t]{4}{*}{$\mathrm{NCI}<\mathrm{AD}$} \\
\hline Low & 13 & 9 & 6 & 28 & & \\
\hline Intermediate & 9 & 4 & 15 & 28 & & \\
\hline High & 0 & 2 & 5 & 7 & & \\
\hline \multicolumn{7}{|c|}{ Distribution of Modified CERAD diagnosis } \\
\hline No & 7 & 7 & 3 & 17 & \multirow[t]{4}{*}{$\mathrm{p}=0.008^{\mathrm{a}}$} & \multirow[t]{4}{*}{$(\mathrm{NCI}, \mathrm{MCI})<\mathrm{AD}$} \\
\hline Possible & 3 & 2 & 3 & 8 & & \\
\hline Probable & 11 & 4 & 10 & 25 & & \\
\hline Definite & 1 & 2 & 10 & 13 & & \\
\hline
\end{tabular}

${ }^{\text {a }}$ Kruskal-Wallis test.

advanced compared to NCI (ANOVA, $\mathrm{p}=0.004$ ), whereas using CERAD criteria the $\mathrm{AD}$ group was more advanced neuropathologically than both NCI and MCI subjects (ANOVA, $\mathrm{p}=0.0008$; table 2). Postmortem neuropathology was not associated with plasma F2-isoprostane levels based upon ordinal logistic regression models.

\section{Discussion}

Despite differences in ages between the NCI, MCI and $\mathrm{AD}$ subjects examined at time of specimen collection, we found no difference in plasma and urine F2A-isoprostane levels, consistent with other reports $[6,15]$. By contrast, others report elevated brain, CSF and plasma F2-isoprostane levels in MCI and $\mathrm{AD}$ [6], suggesting that F2isoprostane levels could act as a biomarker for AD. The inconsistency in using peripheral compared to CSF F2isoprostane level as a biomarker for $\mathrm{AD}$ remains to be determined. Since every cell produces F2-isoprostane, peripheral production unrelated to a particular neurodegenerative disease may easily confound the usefulness of plasma and urine F2-isoprostane levels as a biomarker for AD. Moreover, F2-isoprostane quantification is sensitive to various confounding variables including diet, exercise, body mass index and other diseases associated with lipid peroxidation [16]. These factors as well as methods of measurement vary across studies and could possibly underlie the inconsistency in peripheral F2-isoprostane measurements. However, a comparative study using a variety of analytic measures of plasma and urine F2-isoprostane failed to reproducibly demonstrate an increase in isoprostane levels in AD versus controls [6].

Although we found that postmortem neuropathologic diagnosis of subjects who died since entering the study was not associated with baseline plasma F2-isoprostane levels, brain F2-isoprostane levels correlate with reduction in brain weight and Braak staging $[13,17]$. These findings suggest that brain, but not peripheral F2-isoprostane levels more accurately reflect the burden of underlying AD pathology rather than clinical status. Despite these neuropathological observations, as first reported by Montine et al. [18], plasma F2-isoprostane levels do not appear to be a sensitive biomarker for the clinical progression of $\mathrm{AD}$.

\section{Acknowledgements}

We thank Dr. D. Pratico for performing the F2-isoprostane analysis at the University of Pennsylvania. We are indebted to the support of the participants in the Religious Orders Study; for a list of participating groups see the website http://www. rush.edu/rumc/page-R12394.html. Supported by PO1AG14449, PO1AG09466 and P50AG10161. 


\section{References}

1 Counts SE, Nadeem M, Lad SP, Wuu J, Mufson EJ: Differential expression of synaptic proteins in the frontal and temporal cortex of elderly subjects with mild cognitive impairment. J Neuropathol Exp Neurol 2006; 65:592-601.

-2 Praticò D, MY Lee V, Trojanowski JQ, Rokach J, Fitzgerald GA: Increased F2-isoprostanes in Alzheimer's disease: evidence for enhanced lipid peroxidation in vivo. FASEB J 1998;12:1777-1783.

-3 Praticò D, Iuliano L, Amerio G, Tang LX, Rokach J, Sabatino G, Violi F: Down's syndrome is associated with increased 8,12-iso-iPF2alpha-VI levels: evidence for enhanced lipid peroxidation in vivo. Ann Neurol 2000;48: 795-798.

4 Praticò D, Clark CM, Liun F, Rokach J, Lee VY, Trojanowski JQ: Increase of brain oxidative stress in mild cognitive impairment: a possible predictor of Alzheimer disease. Arch Neurol 2002;59:972-976.

5 Praticò D, Clark CM, Lee VM, Trojanowski JQ, Rokach J, FitzGerald GA: Increased 8,12 iso-iPF2alpha-VI in Alzheimer's disease: correlation of a noninvasive index of lipid peroxidation with disease severity. Ann Neurol 2000;48:809-812.

6 Montine TJ, Montine KS, McMahan W, Markesbery WR, Quinn JF, Morrow JD: F2 isoprostanes in Alzheimer and other neurodegenerative diseases. Antioxid Redox Signal 2005;7:269-275.
Irizarry MC, Yao Y, Hyman BT, Growdon JH, Praticò D: Plasma F2A isoprostane levels in Alzheimer's and Parkinson's disease. Neurodegener Dis 2007;4:403-405

$\checkmark 8$ Ringman JM, Younkin SG, Pratico D, Seltzer W, Cole GM, Geschwind DH, RodriguezAgudelo Y, Schaffer B, Fein J, Sokolow S, Rosario ER, Gylys KH, Varpetian A, Medina LD, Cummings JL: Biochemical markers in persons with preclinical familial Alzheimer disease. Neurology 2008;71:85-92.

9 Bennett DA, Wilson RS, Schneider JA, Evans DA, Beckett LA, Aggarwal NT, Barnes LL, Fox JH, Bach J: Natural history of mild cognitive impairment in older persons. Neurology 2002;59:198-205.

$>10$ Mirra SS, Heyman A, McKeel D Sumi SM, Crain BJ, Brownlee LM, Vogel FS, Hughes JP, van Belle G, Berg L: The consortium to establish a registry for Alzheimer's disease (CERAD). II. Standardization of the neuropathologic assessment of Alzheimer's disease. Neurology 1991;41:479-486.

11 National Institute on Aging and Reagan Institute working group on diagnosis criteria for the neuropathological assessment of $\mathrm{Alz}$ heimer's disease: consensus recommendations for the postmortem diagnosis of AD. Neurobiol Aging 1997;18:S1-S2.

12 Braak H, Braak E: Neuropathological stageing of Alzheimer-related changes. Acta Neuropathol 1991;82:239-259.
13 Forman MS, Mufson EJ, Leurgans S, Praticò D, Joyce S, Leight S, Lee VM, Trojanowski JQ: Cortical biochemistry in MCI and Alzheimer disease: lack of correlation with clinical diagnosis. Neurology 2007;68:757-763.

14 Kirkwood TB: Geometric mean and measures of dispersion. Biometrics 1979;35:908909.

15 Feillet-Coudray C, Tourtauchaux R, Niculescu M, Rock E, Tauveron I, AlexandreGouabau MC, Rayssiguier Y, Jalenques I, Mazur A: Plasma levels of 8-epiPGF2alpha, an in vivo marker of oxidative stress, are not affected by aging or Alzheimer's disease. Free Radic Biol Med 1999;27:463-469.

16 Basu S, Helmersson J: Factors regulating isoprostane formation in vivo. Antioxid Redox Signal 2005;7:221-235.

17 Montine TJ, Markesbery WR, Zackert W, Sanchez SC, Roberts LJ 2nd, Morrow JD: The magnitude of brain lipid peroxidation correlates with the extent of degeneration but not with density of neuritic plaques or neurofibrillary tangles or with APOE genotype in Alzheimer's disease patients. Am J Pathol 1999; 155:863-868.

18 Montine TJ, Quinn JF, Milatovic D, Silbert LC, Dang T, Sanchez S, Terry E, Roberts LJ 2nd, Kaye JA, Morrow JD: Peripheral F2-isoprostanes and F4-neuroprostanes are not increased in Alzheimer's disease. Ann Neurol 2002;52:175-179. 